\title{
A prediction model for lymph node metastases using pathologic features in patients intraoperatively diagnosed as stage I non-small cell lung cancer
}

Fei Zhao ${ }^{\dagger}$, Yue Zhou ${ }^{\dagger}$, Peng-Fei Ge ${ }^{\dagger}$, Chen-Jun Huang, Yue Yu, Jun Li, Yun-Gang Sun, Yang-Chun Meng, Jian-Xia Xu, Ting Jiang, Zhi-Xuan Zhang, Jin-Peng Sun and Wei Wang*

\begin{abstract}
Background: There is little information on which pattern should be chosen to perform lymph node dissection for stage I non-small-cell lung cancer. This study aimed to develop a model for predicting lymph node metastasis using pathologic features of patients intraoperatively diagnosed as stage I non-small-cell lung cancer.

Methods: We collected pathology data from 284 patients intraoperatively diagnosed as stage I non-small-cell lung cancer who underwent lobectomy with complete lymph node dissection from 2013 through 2014, assessing various factors for an association with metastasis to lymph nodes (age, gender, pathology, tumour location, tumour differentiation, tumour size, pleural invasion, bronchus invasion, multicentric invasion and angiolymphatic invasion). After analysing these variables, we developed a multivariable logistic model to estimate risk of metastasis to lymph nodes.

Results: Univariate logistic regression identified tumour size $>2.65 \mathrm{~cm}(p<0.001)$, tumour differentiation $(p<0.001)$, pleural invasion $(p=0.034)$ and bronchus invasion $(p<0.001)$ to be risk factors significantly associated with the presence of metastatic lymph nodes. On multivariable analysis, only tumour size $>2.65 \mathrm{~cm}$ $(p<0.001)$, tumour differentiation $(p=0.006)$ and bronchus invasion $(p=0.017)$ were independent predictors for lymph node metastasis. We developed a model based on these three pathologic factors that determined that the risk of metastasis ranged from $3 \%$ to $44 \%$ for patients intraoperatively diagnosed as stage I non-small-cell lung cancer. By applying the model, we found that the values $\hat{y}>0.80,0.43<\hat{y} \leq 0.80, \hat{y} \leq 0.43$ plus tumour size $>2 \mathrm{~cm}$ and $\hat{y} \leq 0.43$ plus tumour size $\leq 2 \mathrm{~cm}$ yielded positive lymph node metastasis predictive values of $44 \%$, $18 \%, 14 \%$ and $0 \%$, respectively.
\end{abstract}

Conclusions: A non-invasive prediction model including tumour size, tumour differentiation and bronchus invasion may be useful to give thoracic surgeons recommendations on lymph node dissection for patients intraoperatively diagnosed as Stage I non-small cell lung cancer.

Keywords: Non-small-cell lung cancer, Lymph node, Metastasis, Multivariable logistic model

\footnotetext{
* Correspondence: wangwei6707@aliyun.com

${ }^{\dagger}$ Equal contributors

Department of Thoracic Surgery, First Affiliated Hospital of Nanjing Medical

University, 300 Guangzhou Road, Nanjing 210029, China
} 


\section{Background}

Lung cancer is the leading cause of cancer death worldwide [1] and metastasis to lymph nodes directly determines the stage and prognosis of this disease. Computed tomography $(\mathrm{CT})$ remains the most widely used tool for assessment of the tumour and lymph node involvement in patients with early-stage non-small-cell lung cancer (NSCLC) [2-5]. In general, lymph nodes with short-axis diameters of $>1 \mathrm{~cm}$ seen on CT scan are considered metastatic. Unfortunately, the accuracy of CT scan for preoperative lymph node stage is only $45 \%-79 \%$ [2-6]. In addition, studies have demonstrated that $12 \%-17 \%$ of patients histologically confirmed as $\mathrm{N} 2$ are preoperatively diagnosed as NO because their CT scan results showed the involved lymph nodes to have short-axis diameters of $<1 \mathrm{~cm}[4,5,7]$. Many other methods of preoperative $\mathrm{N}$-staging, e.g. positron emission tomography, mediastinoscopy and endoscopic ultrasound-guided fine-needle aspiration, are not routinely used for patients with clinical stage I disease. In addition, these methods yield a considerable number of false-negative results [8-10].

There is ample high-quality evidence on the advantages of lymph node dissection in lung cancer surgery, including the American College of Surgeons Oncology Group (ACOSOG) Z0030 trial [11], although the benefits of complete lymph node dissection for patients with stage I NSCLC are still controversial [12-14]. There is little information on which pattern should be chosen to perform lymph node dissection for patients intraoperatively diagnosed as stage I non-small-cell lung cancer. A non-invasive prediction model that is able to predict lymph node metastasis would allow surgeons to make appropriate decisions on the extent of the dissection, removing lymph nodes that are most likely to contain metastases, while avoiding unnecessary tissue damage in order to accelerate patients' postoperative recovery.

The goal of this study was to identify risk factors that would predict differences in lymph node metastasis and to develop a scoring system to predict the presence of lymph node metastasis. The aim is to determine the appropriate pattern of lymph node dissection for various patients intraoperatively diagnosed as stage I NSCLC.

\section{Methods}

\section{Patient selection}

A total of 284 consecutive patients who underwent surgical resection for primary lung cancer at our hospital from January 2013 to December 2014 were reviewed retrospectively. The records of patients intraoperatively diagnosed as stage I NSCLC who underwent lobectomy with complete lymph node dissection according to the lymph node nomenclature were selected for this study. All patients met the criteria for stage I NSCLC based on the new International Staging System for NSCLC
(National Comprehensive Cancer Network (NCCN) Guidelines Version 3.2014: Staging Non-Small Cell Lung Cancer) [15]. We excluded patients from this study who met any one of the following conditions: 1) tumour size $>4 \mathrm{~cm}$ and lymph node $>1 \mathrm{~cm}$ at the largest diameter on CT imaging or evidence of distant metastasis; 2) preoperative chemotherapy or radiotherapy; 3) previous or coexistent tuberculosis or malignant disease; 4) complete lymph node dissection that did not meet the current standards (i.e. all lymph node stations, including right-hand stations $2-4$ and 7-9 and lefthand stations 2-9); 5) pure ground-glass opacity on CT imaging; 6) synchronous lung cancers, 7) sublobar resection, segmentectomy or partial resection or 8) Intraoperative frozen rapid pathological results showed tumour size $>4 \mathrm{~cm}$ in the largest diameter.

Patients were preoperatively assessed with chest x-ray, chest and upper abdominal CT scan, brain magnetic resonance imaging and bone scintigraphy. CT scan was used for preoperative $\mathrm{N}$-staging. The surgical approach for primary lung cancer resection was via video-assisted thoracic surgery.

\section{Statistical analysis}

The baseline patient characteristics were summarized in percentages for categorical variables and as mean $\pm \mathrm{SD}$ (Standard Deviation) for continuous variables. The chisquare test and Fisher's exact tests were used to analyse differences in these percentages between the groups. Differences between the groups were analysed using the Kruskal-Wallis test. Significance of associations with the outcome of nodal metastases was first evaluated using a univariate logistic analysis. Those significant variables were analysed by multivariable analysis as independent predictors for lymph node metastasis. Odds ratios (ORs) with 95\% confidence intervals (CIs) were calculated. Clinically relevant variables obtained by multivariable analysis were included in the multivariable model. The resulting model coefficients were applied to the cohort to calculate predicted values from the logistic equation: $\hat{y}=1 /[1+\exp .(-x \beta)]$. All confidence intervals, significance tests and resulting $P$ values were two-sided, with an alpha level of 0.05 . Statistical analyses were performed using STATA software, release 13.

\section{Results}

\section{Patient characteristics and prevalence of lymph node} metastasis

A total of 284 patients intraoperatively diagnosed as stage I NSCLC were included in this study. Table 1 shows the patients' demographics and clinical characteristics. The mean age was 60.78 years (range 31-83). Histologically, the tumours in 248 patients (87\%) were identified as adenocarcinoma and in 36 (13\%) as squamous cell carcinoma. The tumour originated in the right upper lobe in 82 patients (29\%), right middle lobe in 16 
Table 1 Patient Demographics and Clinical Characteristics

\begin{tabular}{|c|c|}
\hline Variables & Value \\
\hline Number & 284 \\
\hline \multicolumn{2}{|l|}{ Age (years) } \\
\hline Mean \pm SD (range) & $60.78 \pm 9.2(31-83)$ \\
\hline \multicolumn{2}{|l|}{ Gender (\%) } \\
\hline Male & $144(51 \%)$ \\
\hline Female & $140(49 \%)$ \\
\hline \multicolumn{2}{|l|}{ Pathology } \\
\hline Squamous cell carcinoma & $36(13 \%)$ \\
\hline Adenocarcinoma & $248(87 \%)$ \\
\hline \multicolumn{2}{|l|}{ Tumor location (\%) } \\
\hline Right Upper Lobe & $82(29 \%)$ \\
\hline Right Middle Lobe & $16(6 \%)$ \\
\hline Right Lower Lobe & $39(14 \%)$ \\
\hline Left Upper Lobe & $77(27 \%)$ \\
\hline Left Lower Lobe & $51(18 \%)$ \\
\hline Mixed lobes & $19(6 \%)$ \\
\hline \multicolumn{2}{|l|}{ Differentiation (\%) } \\
\hline । & $86(30 \%)$ \\
\hline$\|$ & $176(62 \%)$ \\
\hline$\|$ & $22(8 \%)$ \\
\hline \multicolumn{2}{|l|}{ Tumor size (cm) } \\
\hline Mean \pm SD (range) & $2.44 \pm 0.97(0.4-4 \mathrm{~cm})$ \\
\hline \multicolumn{2}{|l|}{ Pleura invasion } \\
\hline Absent & $220(77 \%)$ \\
\hline Present & $64(23 \%)$ \\
\hline \multicolumn{2}{|l|}{ Bronchus invasion } \\
\hline Absent & $247(87 \%)$ \\
\hline Present & $37(13 \%)$ \\
\hline \multicolumn{2}{|l|}{ Multicentric invasion (\%) } \\
\hline Absent & $264(93 \%)$ \\
\hline Present & $20(7 \%)$ \\
\hline \multicolumn{2}{|l|}{ Angiolymphatic invasion (\%) } \\
\hline Absent & $274(96 \%)$ \\
\hline Present & $10(4 \%)$ \\
\hline \multicolumn{2}{|l|}{ Neural invasion } \\
\hline Absent & $283(100 \%)$ \\
\hline Present & $1(0 \%)$ \\
\hline
\end{tabular}

SD standard deviation

(6\%), right lower lobe in 39 (14\%), left upper lobe in 77 (27\%), left lower lobe in $51(18 \%)$ and in mixed lobes in 19 (6\%). Mean tumour size was $2.44 \mathrm{~cm}$ (range from 0.4 to $4 \mathrm{~cm})$. The tumour differentiation included I (86 patients, 30\%), II (176 patients, 62\%), III (22 patients, $8 \%)$. Pleural invasion was present in 64 patients $(23 \%)$ and bronchus invasion in 37 (13\%).
Lymph node metastases were not found in 215 patients (group I) but were present in 69 (group II) (Table 2). The characteristics in these two groups were compared in terms of age, gender, pathology, tumour

Table 2 Demographics of patients in the Negative lymph Node Metastases (LNM) and Positive LNM groups

\begin{tabular}{|c|c|c|c|}
\hline \multirow[t]{2}{*}{ Variables } & \multicolumn{2}{|l|}{ Group } & \multirow[t]{2}{*}{$P$ value } \\
\hline & Negative LNM & Positive LNM & \\
\hline Number & 215 & 69 & \\
\hline Age (years) & & & 0.118 \\
\hline Mean \pm SD & $61.27 \pm 9.38$ & $59.28 \pm 8.49$ & \\
\hline Gender & & & 0.997 \\
\hline Male & 109 & 35 & \\
\hline Female & 106 & 34 & \\
\hline Pathology & & & 0.176 \\
\hline Squamous cell carcinoma & 24 & 12 & \\
\hline Adenocarcinoma & 191 & 57 & \\
\hline Tumor location & & & 0.368 \\
\hline Right Upper Lobe & 62 & 20 & \\
\hline Right Middle Lobe & 14 & 2 & \\
\hline Right Lower Lobe & 28 & 11 & \\
\hline Left Upper Lobe & 63 & 14 & \\
\hline Left Lower Lobe & 34 & 17 & \\
\hline Mixed lobes & 14 & 5 & \\
\hline Differentiation & & & $<0.001^{*}$ \\
\hline । & 80 & 6 & \\
\hline$\|$ & 119 & 57 & \\
\hline III & 16 & 6 & \\
\hline Tumor size $(\mathrm{cm})$ & & & $<0.001$ \\
\hline Mean \pm SD & $2.28 \pm 0.95$ & $2.92 \pm 0.87$ & \\
\hline Pleura invasion & & & $0.033^{*}$ \\
\hline Absent & 173 & 47 & \\
\hline Present & 42 & 22 & \\
\hline Bronchus invasion & & & $<0.001^{*}$ \\
\hline Absent & 196 & 51 & \\
\hline Present & 19 & 18 & \\
\hline Multicentric invasion & & & 1 (Fish) \\
\hline Absent & 200 & 64 & \\
\hline Present & 15 & 5 & \\
\hline Angiolymphatic invasion & & & 0.263 (Fish) \\
\hline Absent & 209 & 65 & \\
\hline Present & 6 & 4 & \\
\hline Neural invasion & & & 1.0 (Fish) \\
\hline Absent & 214 & 69 & \\
\hline Present & 1 & 0 & \\
\hline
\end{tabular}

$S D$ standard deviation ${ }^{*} P<0.05$ 
location, tumour differentiation, tumour size, pleural invasion, bronchus invasion, multicentric invasion, neural invasion and angiolymphatic invasion. Compared with group I, group II had a significantly larger tumour size than that in group I $(2.92 \pm 0.87$ vs. $2.28 \pm 0.95$, $P<0.001)$. There were significant statistical differences between the groups by the $x^{2}$ test in terms of tumour differentiation (I, II, III) $(P<0.001)$, bronchus invasion (absent vs. present) $(P<0.001)$ and pleural invasion (absent vs. present) $(P=0.033)$.

To evaluate the predictive value of tumour size between the groups, we used Receiver Operating Characteristic (ROC) curve analysis. As shown in Fig. 1, the area under the ROC curve for tumour size between group I and group II was 0.691 (95\% CI: $0.621-0.761 ; P<0.001)$; the optimal cut-off value was $2.650 \mathrm{~cm}$ (sensitivity: 67\%; specificity: 70\%; Youden's index: 0.364).

\section{Association of Individual Pathologic Characteristics with Nodal Metastasis}

Univariate analysis showed that tumour size greater than $2.650 \mathrm{~cm}(\mathrm{OR}=4.62,95 \%$ CI 2.59-8.24; $P<0.001)$, tumour differentiation (I vs II + III, OR $=6.22,95 \%$ CI 2.58-15.03; $P<0.001$ ), pleural invasion (absent vs present, $\mathrm{OR}=1.93,95 \%$ CI $1.05-3.54 ; P=0.034)$ and bronchus invasion (absent vs present, OR $=3.64,95 \% \mathrm{CI}$ 1.78-7.44; $P<0.001$ ) were the four significant risk factors associated with the presence of metastatic lymph nodes (Table 3).

\section{Multivariable analysis of pathologic characteristics associated with nodal metastasis}

Multivariate analysis of the four risk factors obtained on univariate analysis showed that only the tumour size $(\leq 2.65 \mathrm{~cm}$ vs. $>2.65 \mathrm{~cm}$, OR $=3.23,95 \%$ CI $1.75-5.93$; $P<0.001$ ), tumour differentiation (I vs II + III, OR $=3.64,95 \%$ CI 1.44-9.16; $P=0.006)$ and bronchus invasion (absent vs. present, OR $=2.54,95 \%$ CI 1.18-5.46; $P=0.017)$ were independent predictors associated with the presence of metastatic lymph nodes. However, pleural invasion (absent vs. present, OR $=1.64,95 \% \mathrm{CI}$ $0.84-3.21 ; P=0.146)$ was not a significant predictor of lymph node metastasis (Table 4).

\section{Multivariable logistic regression model derivation and development}

On multivariable analysis, only three covariates remained in the final model. Using these three variables (Table 5), a scoring system was developed to discriminate between patients with and without lymph node metastasis. The risk scores for individual patients were calculated using the following formula: $\mathrm{x} \beta=-2.947+(1.368 \times$ Differentiation (I vs. II + III, $I=0, \mathrm{II}+\mathrm{III}=1))+(1.188 \times$ Tumour Size $(2.65 \mathrm{~cm}$ vs. $>2.65 \mathrm{~cm}, \leq 2.65 \mathrm{~cm}=0,>2.65 \mathrm{~cm}=1))+(0.876 \times$ Bronchus Invasion (absent $=0$, present $=1)$ ).

The probabilities of lymph node metastasis were calculated using the following formula $(\hat{y}=1 /$ $[1+$ exp. $(-x \beta)]): \hat{y}=1 /[1+\exp .(2.947-(1.368 \times$ Differentiation (I vs. II + III, $I=0$, II + III $=1))-(1.188 \times$ Tumour Size $(\leq 2.65 \mathrm{~cm}$ vs. $>2.65 \mathrm{~cm}, \leq 2.65 \mathrm{~cm}=0,>2.65 \mathrm{~cm}=1))$ - $(0.876 \times$ Bronchus Invasion (absent $=0$, present $=1))$ ].

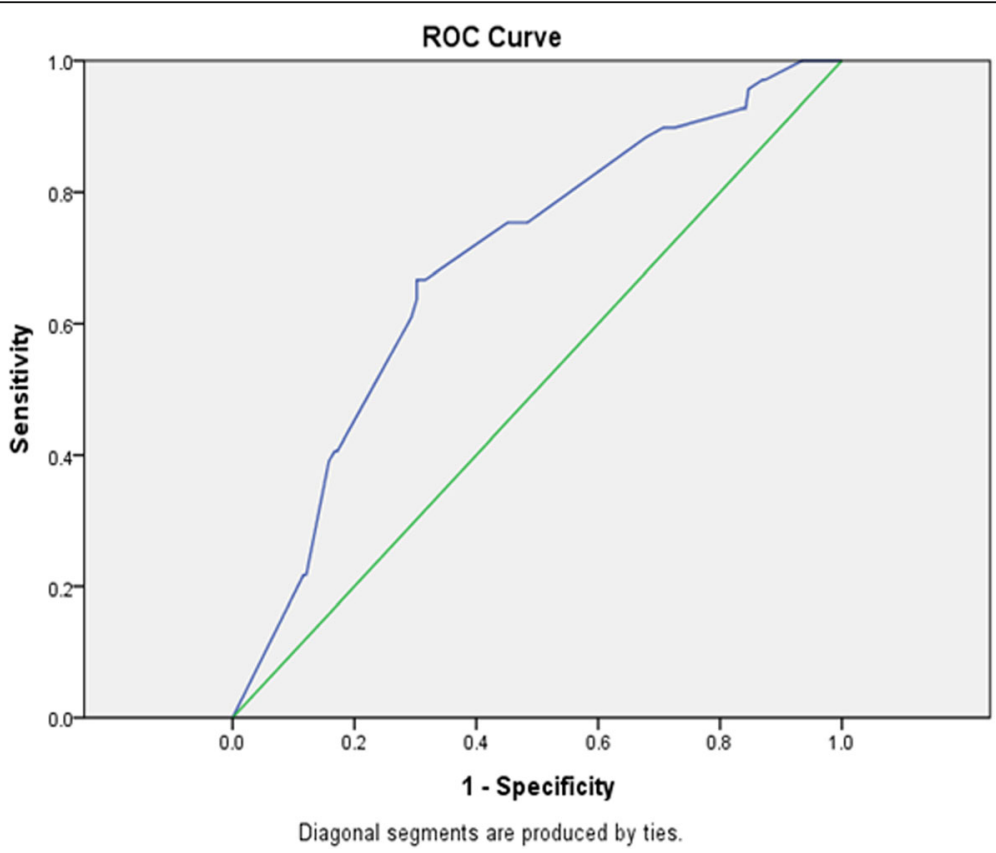

Fig. 1 The ROC (Receiver Operating Characteristic) curve of tumor size between group I and group II 
Table 3 Univariate analysis of the risk factors for lymph node metastases

\begin{tabular}{|c|c|c|}
\hline Variables & OR $(95 \% \mathrm{Cl})$ & $P$ value \\
\hline \multicolumn{3}{|l|}{ Age } \\
\hline$\leq 60$ vs $>60$ & $0.75(0.44-1.30)$ & 0.304 \\
\hline \multicolumn{3}{|l|}{ Gender } \\
\hline male vs female & $1.0(0.58-1.72)$ & 0.997 \\
\hline \multicolumn{3}{|l|}{ Pathology } \\
\hline $\begin{array}{l}\text { Squamous cell carcinoma VS } \\
\text { Adenocarcinoma }\end{array}$ & $0.60(0.28-1.27)$ & 0.179 \\
\hline \multicolumn{3}{|l|}{ Tumor location } \\
\hline Right lobes vs Left lobes & $1.00(0.57-1.77)$ & 0.98 \\
\hline Upper lobes vs Middle + Left lobes & $1.45(0.82-2.56)$ & 0.199 \\
\hline Single lobes vs Mixed lobes & $1.12(0.39-3.24)$ & 0.832 \\
\hline \multicolumn{3}{|l|}{ Differentiation } \\
\hline | VS || + ||| & $6.22(2.58-15.03)$ & $<0.001^{*}$ \\
\hline \multicolumn{3}{|l|}{ Tumor size } \\
\hline$\leq 2.65 \mathrm{~cm}$ vs $>2.65 \mathrm{~cm}$ & $4.62(2.59-8.24)$ & $<0.001^{*}$ \\
\hline \multicolumn{3}{|l|}{ Pleura invasion } \\
\hline Absent vs Present & $1.93(1.05-3.54)$ & $0.034^{*}$ \\
\hline \multicolumn{3}{|l|}{ Bronchus invasion } \\
\hline Absent vs Present & $3.64(1.78-7.44)$ & $<0.001^{*}$ \\
\hline \multicolumn{3}{|l|}{ Multicentric invasion } \\
\hline Absent vs Present & $1.04(0.36-2.98)$ & 0.939 \\
\hline \multicolumn{3}{|l|}{ Angiolymphatic invasion } \\
\hline Absent vs Present & $2.14(0.59-7.83)$ & 0.249 \\
\hline
\end{tabular}

Model performance and selecting cut-off values to discriminate patients with lymph node metastasis

As shown in Fig. 2, the area under the ROC curve of the selected model was 0.753 (95\% CI 0.692-0.814, standard error 0.031 ) and the optimal cut-off value was $0.7997 \approx 0.80$ (sensitivity: $71 \%$, specificity: $71 \%$, Youden's index: 0.417). In all patients, using a score threshold of

Table 4 Multivariate analysis of the risk factors for lymph node metastases

\begin{tabular}{|c|c|c|c|}
\hline Variables & $\beta$ & OR $(95 \% \mathrm{Cl})$ & $P$ value \\
\hline \multicolumn{4}{|l|}{ Differentiation } \\
\hline | VS || + ||| & 1.291 & $3.64(1.44-9.16)$ & $0.006^{*}$ \\
\hline \multicolumn{4}{|l|}{ Tumor size } \\
\hline$\leq 2.65 \mathrm{~cm}$ vs $>2.65 \mathrm{~cm}$ & 1.171 & $3.23(1.75-5.93)$ & $<0.001^{*}$ \\
\hline \multicolumn{4}{|l|}{ Pleura invasion } \\
\hline Absent vs Present & 0.496 & $1.64(0.84-3.21)$ & 0.146 \\
\hline \multicolumn{4}{|l|}{ Bronchus invasion } \\
\hline Absent vs Present & 0.931 & $2.54(1.18-5.46)$ & $0.017^{*}$ \\
\hline Intercept & -3.013 & & \\
\hline
\end{tabular}

${ }^{*} P<0.05$
Table 5 Multivariate analysis of the risk factors for development of model

\begin{tabular}{|c|c|c|c|}
\hline Variables & $\beta$ & OR $(95 \% \mathrm{Cl})$ & $P$ value \\
\hline \multicolumn{4}{|l|}{ Differentiation } \\
\hline | VS || + III & 1.368 & $3.93(1.57-9.83)$ & $0.003^{*}$ \\
\hline \multicolumn{4}{|l|}{ Tumor size } \\
\hline$\leq 2.65 \mathrm{~cm}$ vs $>2.65 \mathrm{~cm}$ & 1.188 & $3.28(1.79-6.01)$ & $<0.001^{*}$ \\
\hline \multicolumn{4}{|l|}{ Bronchus invasion } \\
\hline Absent vs Present & 0.876 & $2.40(1.13-5.13)$ & $0.023^{*}$ \\
\hline Intercept & -2.947 & & \\
\hline
\end{tabular}

$\leq 0.80,20$ (12\%) of 172 patients with lymph node metastasis were correctly identified, whereas 152 (88\%) of 172 without lymph node metastasis were correctly identified. Using a score threshold of >0.80, 49 (44\%) of 112 patients with lymph node metastasis were correctly identified, whereas 63 (56\%) of 112 without lymph node metastasis were correctly identified.

When all three covariates (tumour size, tumour differentiation, bronchus invasion) were equal to zero, we found that the cut-off value was $0.42685 \approx 0.43$. In all patients, using a score threshold of $\leq 0.43,2(3 \%)$ of 71 patients with lymph node metastasis were correctly identified, whereas 69 (97\%) of 71 without lymph node metastasis were correctly identified. Using a score threshold of $>0.43,67$ (31\%) of 213 patients with lymph node metastasis were correctly identified, whereas 146 (69\%) of 213 without lymph node metastasis were correctly identified.

Using a score threshold between 0.43 and 0.80, 18 (18\%) of 101 patients with lymph node metastasis were correctly identified, whereas 83 (82\%) of 101 without lymph node metastasis were correctly identified. So, we obtained three score thresholds, $\hat{y} \leq 0.43,0.43<\hat{y} \leq 0.80$ and $\hat{y}>0.80$.

\section{Discussion}

A complete lymph node dissection, removing all ipsilateral lymph nodes which can be seen at operation [16], can provide more accurate pathologic staging and better clinical outcomes for some patients. It is considered a standard surgical treatment for patients diagnosed preoperatively with lymph node metastases. However, complete lymph node dissection is not regarded as a routine surgical procedure for patients intraoperatively diagnosed as stage I NSCLC, as some studies have demonstrated a lack of significant differences in outcome between selective lymph node sampling and complete lymph node dissection in patients with earlystage lung cancer $[13,17]$.

However each patient exhibits different clinical characteristics that affect the risk of lymph node metastasis in early-stage lung cancer. In this study, we collected 


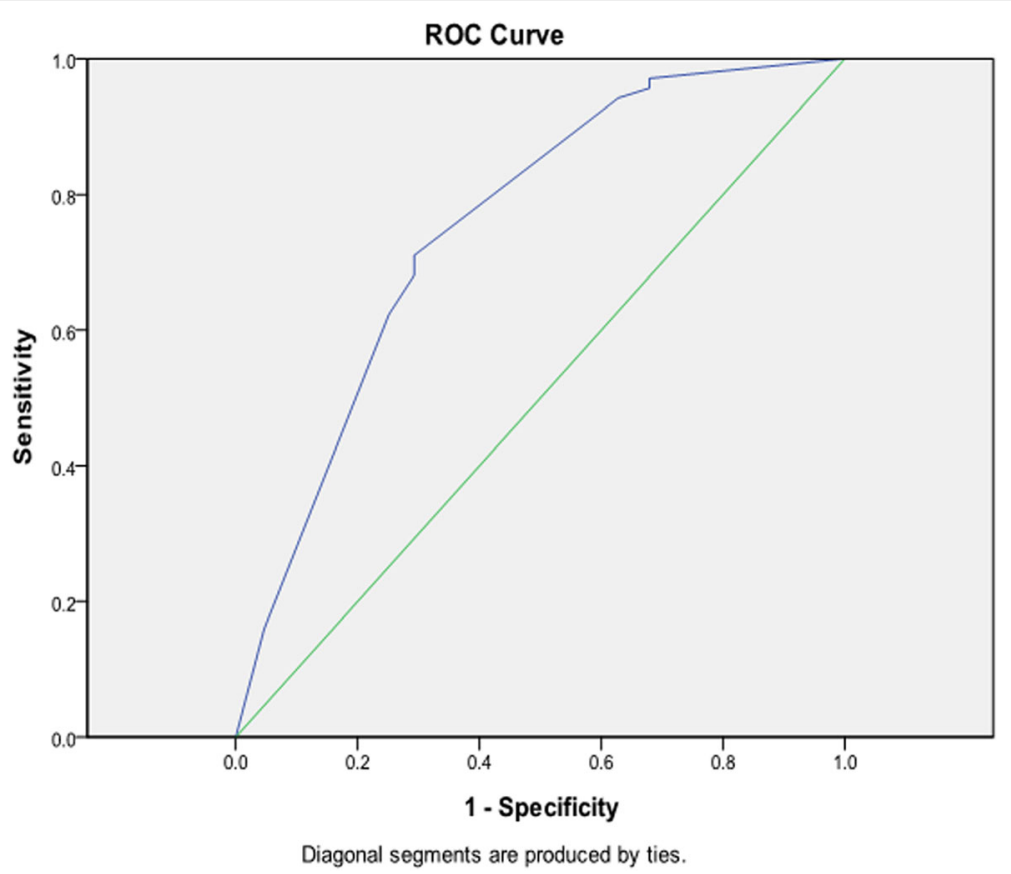

Fig. 2 The ROC (Receiver Operating Characteristic) curve of the selected model

pathology data from 284 patients intraoperatively diagnosed as stage I NSCLC who underwent lobectomy with complete lymph node dissection and investigated factors that might be associated with metastasis to lymph nodes (age, gender, pathology, tumour location, tumour differentiation, tumour size, pleural invasion, bronchus invasion, multicentric invasion and angiolymphatic invasion).

First, we used univariate analysis to find associations between pathologic factors and lymph node metastasis. The results showed that only the tumour size $(>2.65 \mathrm{~cm})$, tumour differentiation, pleural invasion and bronchus invasion were significant risk factors. The other factors tested, including age, gender, pathologic type, tumour location, multicentric invasion, angiolymphatic invasion and neural invasion were excluded as risk factors associated with lymph node metastasis.

Furthermore, multivariate analysis of the four risk factors identified on univariate analysis found that only tumour size $(>2.65 \mathrm{~cm})$, tumour differentiation and bronchus invasion were independent predictors of lymph node metastasis. Pleural invasion was excluded as an independent predictor in this analysis.

These three independent predictors were kept in the final model. After developing the multivariable logistic regression model, we finally obtained three score thresholds, $\hat{y} \leq 0.43,0.43<\hat{y} \leq 0.80$ and $\hat{y}>0.80$ (Table 6). As shown

Table 6 Analysis of lymph Node Metastases (LNM)

\begin{tabular}{|c|c|c|c|c|c|c|c|c|c|}
\hline \multirow[t]{2}{*}{ Variables } & \multicolumn{3}{|l|}{$\hat{y} \leq 0.43$} & \multicolumn{3}{|l|}{$0.43 \sim 0.80$} & \multicolumn{3}{|l|}{$\hat{y}>0.80$} \\
\hline & Negative LNM & Positive LNM (\%) & Total & Negative LNM & Positive LNM (\%) & Total & Negative LNM & Positive LNM (\%) & Total \\
\hline Num & 69 & 2(3) & 71 & 83 & $18(18)$ & 101 & 63 & $49(44)$ & 112 \\
\hline \multicolumn{10}{|c|}{ Differentiation } \\
\hline । & 69 & 2(3) & 71 & 11 & $2(15)$ & 13 & 0 & $2(100)$ & 2 \\
\hline$\|+\|$ & - & - & - & 72 & $16(18)$ & 88 & 63 & $47(43)$ & 110 \\
\hline \multicolumn{10}{|c|}{ Tumor size(cm) } \\
\hline$\leq 2$ & 57 & $0(0)$ & 57 & 50 & $13(20)$ & 64 & 4 & $4(50)$ & 8 \\
\hline $2 \sim 2.65$ & 12 & $2(14)$ & 14 & 22 & $4(15)$ & 26 & 5 & $0(0)$ & 5 \\
\hline$>2.65$ & - & - & - & 11 & $1(8)$ & 12 & 54 & $45(45)$ & 99 \\
\hline \multicolumn{10}{|c|}{ Bronchus invasion } \\
\hline Absent & 69 & $2(3)$ & 71 & 83 & $17(17)$ & 100 & 44 & $32(42)$ & 76 \\
\hline Present & - & - & - & 0 & $1(100)$ & 1 & 19 & $17(47)$ & 36 \\
\hline
\end{tabular}


in the table, we found that when $\hat{y}$ was $\leq 0.43$, patients with lymph node metastasis accounted for $3 \%$ of all patients, and when $\hat{y}$ was $\leq 0.43$ and tumour size was $\leq 2 \mathrm{~cm}$, no patients had lymph node metastasis. However, when $\hat{y}$ was $\leq 0.43$ and tumour size was $>2 \mathrm{~cm}$, the percentage of patients identified with lymph node metastasis increased to $14 \%$. With $0.43<\hat{y} \leq 0.80$, patients with lymph node metastasis accounted for $18 \%$ of all patients. When $\hat{y}$ was $>0.80$, the patients with lymph node metastasis accounted for $44 \%$ of all patients.

Thus we demonstrated that lymph node dissection is not necessary for those patients intraoperatively diagnosed as stage I NSCLC whose $\hat{y}$ value obtained from the model is less than or equal to 0.43 and whose tumour size is $\leq 2 \mathrm{~cm}$. Complete lymph node dissection or lymph node sampling would be appropriate if the $\hat{y}$ value from the model is less than or equal to $0.43 \mathrm{but}$ the tumour size is $>2 \mathrm{~cm}$ or if $\hat{y}$ is more than 0.43 and less than or equal to 0.80 . Complete lymph node dissection must be performed for patients whose $\hat{y}$ value obtained from the model is more than 0.80 .

However, our study has some limitations. This study was conducted at a single institution with retrospective methods and demonstrated the necessity of further prospective study. Further prospective study with multicenter trial should be performed to comprehensively evaluate this model for prediction of lymph node metastases in patients intraoperatively diagnosed as Stage I non-small cell lung cancer.

\section{Conclusions}

After a comprehensive analysis of our results concerning various clinical factors, we conclude that the incidence of lymph node metastasis would be lowest when we obtained a $\hat{y}$ value from the model less than or equal to 0.43 along with a tumour size $\leq 2 \mathrm{~cm}$. For other patients intraoperatively diagnosed as stage I NSCLC, the risk of lymph node lymph node metastasis was greater, so that and complete lymph node dissection or lymph node sampling is necessary.

\section{Additional file}

Additional file 1: Support file containing the Age ranges, Pathology, location, Differentiation, Tumor size $2.65 \mathrm{~cm}$, Pleura invasion, Bronchus invasion, Multicentric invasion, Angiolymphatic invasion, Neural invasion and LNM (lymph node metastasis) described in categorical variables and Tumorsize, $\times \beta$ and $\hat{y}$ described in continuous variables. (XLSX $32 \mathrm{~kb}$ )

\section{Abbreviations}

ACOSOG: American College of Surgeons Oncology Group; CT: Computed tomography; NSCLC: Non-small-cell lung cancer; ROC: Receiver Operating Characteristic; SD: Standard Deviation

\section{Acknowledgments}

We thank Dr. Liang Chen and Dr. Quan Zhu for their constructive suggestions and comments.

\section{Funding}

This work was supported by Natural Science Foundation of Jiangsu Province (BK20151589) which provided funds for collection and analysis of clinical data.

\section{Availability of data and materials}

We presented raw data within Additional file 1.

\section{Authors' contributions}

ZF and ZY drafted the manuscript. GP, HC, YY, LJ, SY, MY, XJ, JT, ZZ, SJ participated in collecting clinical data and performed the statistical analysis. WW conceived of the study, and participated in its design and coordination and helped to draft the manuscript. All authors read and approved the final manuscript.

\section{Competing interests}

The authors declare that they have no competing interests.

\section{Consent for publication}

Not applicable.

\section{Ethics approval and consent to participate}

This study was conducted in accordance with the amended Declaration of Helsinki. The approval of the Ethical Committee of Nanjing Medical University was obtained (project approval no. 2012-SRFA-161). The written informed consent from either the patients or their representatives was waived due to the retrospective nature of this study in accordance with the American Medical Association.

\section{Publisher's Note}

Springer Nature remains neutral with regard to jurisdictional claims in published maps and institutional affiliations.

Received: 18 December 2016 Accepted: 7 April 2017

Published online: 13 April 2017

\section{References}

1. Reif MS, Socinski MA, Rivera MP. Evidence-based medicine in the treatment of non-small-cell lung cancer. Clin Chest Med. 2000;21:107-20. ix

2. Gdeedo A, Van Schil P, Corthouts B, Van Mieghem F, Van Meerbeeck J, Van Marck E. Prospective evaluation of computed tomography and mediastinoscopy in mediastinal lymph node staging. Eur Respir J. 1997:10:1547-51.

3. Gupta NC, Graeber GM, Bishop HA. Comparative efficacy of positron emission tomography with fluorodeoxyglucose in evaluation of small $(<1$ $\mathrm{cm})$, intermediate (1 to $3 \mathrm{~cm})$, and large $(>3 \mathrm{~cm}$ ) lymph node lesions. Chest. 2000;117:773-8.

4. Prenzel KL, Monig SP, Sinning JM, Baldus SE, Brochhagen HG, Schneider PM, Holscher AH. Lymph node size and metastatic infiltration in non-small cell lung cancer. Chest. 2003;123:463-7.

5. Sioris T, Jarvenpaa R, Kuukasjarvi $P$, Helin H, Saarelainen S, Tarkka M. Comparison of computed tomography and systematic lymph node dissection in determining TNM and stage in non-small cell lung cancer. Eur J Cardiothorac Surg. 2003;23:403-8.

6. Steinert HC, Hauser M, Allemann F, Engel H, Berthold T, von Schulthess GK, Weder W. Non-small cell lung cancer: nodal staging with FDG PET versus CT with correlative lymph node mapping and sampling. Radiology. 1997;202:441-6.

7. Izbicki JR, Passlick B, Pantel K, Pichlmeier U, Hosch SB, Karg O, Thetter O. Effectiveness of radical systematic mediastinal lymphadenectomy in patients with resectable non-small cell lung cancer: results of a prospective randomized trial. Ann Surg. 1998;227:138-44.

8. Hermens FH, Van Engelenburg TC, Visser FJ, Thunnissen FB, Termeer R, Janssen JP. Diagnostic yield of transbronchial histology needle aspiration in patients with mediastinal lymph node enlargement. Respiration. 2003;70:631-5.

9. Annema JT, Veselic M, Versteegh MI, Willems LN, Rabe KF. Mediastinal restaging: EUS-FNA offers a new perspective. Lung Cancer. 2003:42:311-8. 
10. Freixinet Gilart J, Garcia PG, de Castro FR, Suarez PR, Rodriguez NS, de Ugarte AV. Extended cervical mediastinoscopy in the staging of bronchogenic carcinoma. Ann Thorac Surg. 2000;70:1641-3.

11. Allen MS, Darling GE, Pechet TT, Mitchell JD, Herndon 2nd JE, Landreneau $\mathrm{RJ}$, Inculet RI, Jones DR, Meyers BF, Harpole DH, et al. Morbidity and mortality of major pulmonary resections in patients with early-stage lung cancer: initial results of the randomized, prospective ACOSOG Z0030 trial. Ann Thorac Surg. 2006;81:1013-9. discussion 1019-1020

12. Kim S, Kim HK, Kang DY, Jeong JM, Choi YH. Intra-operative sentinel lymph node identification using a novel receptor-binding agent (technetium-99m neomannosyl human serum albumin, 99mTc-MSA) in stage I non-small cell lung cancer. Eur J Cardiothorac Surg. 2010;37:1450-6.

13. Naruke T, Tsuchiya R, Kondo H, Nakayama H, Asamura H. Lymph node sampling in lung cancer: how should it be done? Eur J Cardiothorac Surg. 1999:16(Suppl 1):S17-24.

14. Silverberg SG, Connolly JL, Dabbs D, Muro-Cacho CA, Page DL, Ray MB, Wick MR. Recommendations for processing and reporting of lymph node specimens submitted for evaluation of metastatic disease. Am J Clin Pathol. 2001;115:799-801.

15. Rami-Porta R, Bolejack V, Giroux DJ, Chansky K, Crowley J, Asamura H, Goldstraw P. The IASLC lung cancer staging project: the new database to inform the eighth edition of the TNM classification of lung cancer. J Thorac Oncol. 2014;9:1618-24

16. Martini N. Mediastinal lymph node dissection for lung cancer. The memorial experience. Chest Surg Clin N Am. 1995;5:189-203.

17. Jeon HW, Moon MH, Kim KS, Kim YD, Wang YP, Park HJ, Park JK. Extent of removal for mediastinal nodal stations for patients with clinical stage I nonsmall cell lung cancer: effect on outcome. Thorac Cardiovasc Surg. 2014;62:599-604.

\section{Submit your next manuscript to BioMed Central and we will help you at every step:}

- We accept pre-submission inquiries

- Our selector tool helps you to find the most relevant journal

- We provide round the clock customer support

- Convenient online submission

- Thorough peer review

- Inclusion in PubMed and all major indexing services

- Maximum visibility for your research

Submit your manuscript at www.biomedcentral.com/submit 